OSOBA I WARTOŚCI

Filozofia Chrzé́cijańsKa • TOM 8, Poznań 2011

Uniwersytet im. Adama Mickiewicza - Wydziat Teologiczny

\author{
RYSZARD WIŚNIEWSKI \\ Uniwersytet Mikołaja Kopernika w Toruniu \\ Wydział Humanistyczny \\ Instytut Filozofii \\ Zakład Aksjologii i Etyki Społecznej
}

\title{
Interesy i wartości, użyteczność i godność - o potrzebie interwencji w moralne gry językowe
}

\author{
Interests and Values, Utility and Dignity \\ - On the Necessity of Intervention into Moral Language-Games
}

Przedmiotem rozważań, ale w pewnym sensie także punktem wyjścia czyni się tutaj dwie kwestie: interesy (zainteresowania) jako źródłowy punkt wyjścia dla uchwycenia wartości przedmiotów oraz użyteczność więzi między ludźmi jako punkt odniesienia dla uchwycenia aksjologicznej istoty godności. Drogą jaką prowadzę te rozważania, jest dobrze znany z historii filozofii trop poszukiwania najbardziej podstawowej odpowiedzi na dwa pytania: co to (czym) są wartości i jakie są wartości? To są dwa pytania, które leżą u podstaw aksjologii i etyki wartości ${ }^{1}$.

Artykuł nawiązuje do wystapienia w sprawie bełkotu aksjologicznego w dyskusjach operujących językiem wartości i ma przede wszystkim charakter refleksyjno-krytyczny, oparty jest bowiem o doświadczenie gier językowych obecnych w życiu publicznym, w szczególności w kodyfikacjach etycznych zawodowych i instytucjonalnych, ale także w literaturze moralistycznej.

${ }^{1}$ Na znaczenie tych dwóch pytań naprowadza: W. Tatarkiewicz, Problemy aksjologii, thum. A. Wiśniewska, „Ruch Filozoficzny”, LXVII, 2010, 4, s. 813 - thum. z oryg.: Les problèmes en axiologie. Argument écrit, „Actualités Scientifiques et Industrielles” nr 1078. VI. Nature et problèmes en philosophie (Entretiens d'été - Lund 1947). III. Le problème dans les sciences humaines, Paris 1949, p. 33-36.

${ }^{2}$ Por. R. Wiśniewski, Bełkot aksjologiczny we wspótczesnej komunikacji, w: Co się dzieje z wartościami? Próba diagnozy. „Colloquia Disputiones” 12, red. E. Okońska, K. Stachewicz, Poznań 2009, s. 157-172. 
Filozofia, a w szczególności filozofia moralna, może być użyteczna społecznie jako pozytywna krytyka etosu, czyli jako pozytywna rekonstrukcja konceptualizacji i instytucjonalizowanych praktyk moralnych. Punktem odniesienia dla tej refleksji mogą być zarówno niektóre głośniejsze teorie etyczne (Arystotelesa i Kanta), jak i mniej znane, a warte przypomnienia lub zwrócenia uwagi. Tekst ten jest w szczególności wymierzony przeciwko nadużyciu słowa „bezinteresowność” z jednej strony, a następnie - przeciwko trywializacji pojęcia „godność” w publicznych dyskursach.

\section{INTERESY I WARTOŚCI}

Język potoczny i język publicznego (zwykle medialnego) dyskursu etycznego zdają się przeciwstawiać sobie interesy i wartości, interesowność i etyczną bezinteresowność. W tym kontekście każdorazowe wykazywanie komuś, że ma w czymś interes, stanowi zwykle asumpt do kwestionowania moralnej wartości jego czynu. Rzecz nie jest jednak tak prosta, jakby się na pierwszy rzut oka wydawało. Zwykły namysł prowadzi bowiem do konstatacji, że słowa „interes” używamy najczęściej w kontekście pragmatyczno-materialnym, zarówno w perspektywie indywidualnej, jak i grupowej (czyjś interes, czyjeś interesy, grupowe, narodowe interesy). Ze słowem ,interes”, kojarzonym w pierwszym rzędzie z tym, co pożyteczne, opłacalne, korzystne, wiążemy również terminy pochodne, takie jak: zainteresowanie, interesowność, interesować się, zainteresowany, ale także - wracając na grunt ekonomiczny - interesowany czy interesariusz.

Słownikowe ujęcia wskazują na łacińskie źródło słowa ,interes”, odsyłając do inter-esse. W Słowniku etymologicznym języka polskiego czytamy, że zdaniem A. Brücknera jest to „europejska pożyczka z łac. interesse, wprowadzona do polszczyzny w XVI wieku, zapewne za pośrednictwem niem. Interesse, por. franc. interesse 'zainteresowany', ang. interest 'zainteresowanie', $[\ldots]^{3} . \mathrm{Z}$ analizy innych słowników wynika, że przez interes należy rozumieć przede wszystkim: sprawę, pożytek, korzystne przedsięwzięcie, dobrze prosperujące przedsiębiorstwo (własny interes). Interesowność uważa się tam jednak za termin przestarzały, ale w dalszej kolejności - zainteresowanie ${ }^{4}$.

Widać, że czysto opisowy sens słowa „interes” graniczy z formą językową określaną jako zainteresowanie i jednoznacznie wyraża sens aksjologicz-

\footnotetext{
${ }^{3}$ K. Długosz-Kurczabowa, Stownik etymologiczny języka polskiego, Warszawa 2006, s. 190.

${ }^{4}$ Por. Mały słownik języka polskiego, red. S. Skorupka, H. Auderska, Z. Łempicka, Warszawa 1974, s. 238. Także: Słownik wyrazów obcych, Warszawa 1980, s. 310-311.
} 
ny tego słowa. Śledzenie rozmaitych znaczeń i użytków słowa „interes” i jego pochodnych może okazać się ciekawym zajęciem, ale porządkowanie znaczeń i pragmatycznych kontekstów użycia słowa „interes” pozostawmy językoznawcom. Chodzi nam przede wszystkim o uchwycenie obecności sensu aksjologicznego w terminologii narosłej wobec słowa ,interes" i jego pochodnych form. A sensu tego, już nie tylko semantycznego, trzeba szukać w początkach nauki o wartościowaniu i wartościach.

Refleksja nad wartościowaniem i wartościami wyrasta z greckiej etyki, z jej teorii duszy i teleologii. To, co dzisiaj określamy słowami ,interes” lub „zainteresowanie”, miało swój aksjologiczny pierwowzór w terminach: orexis, oznaczającym pragnienie właściwe nierozumnej części duszy, a idąc dalej także w boulesis - odnoszącym się do pragnienia rozumnego. Jedne i drugie pragnienia określają w etyce Arystotelesa ludzkie dążenia skierowane ku dobru. Przedmiotem dążenia jest dobro, a przedmiotem unikania zło ${ }^{5}$. To jest aksjomat semantyczno-aksjologiczny filozofii greckiej, jakkolwiek potraktujemy dobro i zło - subiektywistycznie czy obiektywistycznie. Chodzi tu oczywiście o pytanie, czy to dążenie i unikanie czyni jakieś przedmioty dobrymi i złymi, czy może przeciwnie - dobro bądź zło przedmiotów sprawia, że do nich dążymy bądź ich unikamy. Refleksja nad tą relacją wyznacza jeden z najtrudniejszych problemów teoretycznych etyki, estetyki, a w konsekwencji po wiekach - aksjologii.

Greckie dążenie do dobra znajduje swój rozwinięty ekwiwalent pojęciowy w tym, co na gruncie kultury łacińskiej wiąże się ze słowem inter-esse, a poniekąd może się odnosić też do inter-res (na co jednak słowniki nie zwracają uwagi). Zbitka słów inter i esse oznacza relację „między” lub „do” „bycia” (względnie w przypadku inter-res względem „rzeczy”). Jasne jest, że relacja z natury swej, jeśli jest od-osobowa lub międzyosobowa, nie może być neutralna aksjologicznie, obojętna. Wskazuje na to powoływana już analiza etymologiczna, zwracająca uwagę na to, że pierwotne inter-esse uległo w języku polskim ewolucji przenoszącej ciężar znaczenia na sferę utylitarno-merkantylną ${ }^{6}$ W konfrontacji z głębszym filozoficznym sensem słowa i postawy

\footnotetext{
${ }^{5}$ Por. Arystoteles, Etyka nikomachejska, gdzie w słynnym zdaniu otwierającym tekst księgi pierwszej czytamy: „Wszelka sztuka i wszelkie badanie, a podobnie też wszelkie działanie i postanowienie, zdają się zdążać do jakiegoś dobra i dlatego trafnie określano dobro jako cel wszelkiego dążenia" - w przekładzie D. Gromskiej, w: Arystoteles, Dzieła wszystkie, t. 5, Warszawa 1996, s. 77.

${ }^{6}$ Por. K. Długosz-Kurczabowa, Słownik etymologiczny języka polskiego, gdzie czytamy: „Ogólną tendencją rozwoju znaczeniowego wyrazu interes jest rozszerzanie jego zakresu i w pewnym stopniu konkretyzacja: najpierw 'pożytek', 'korzyść'; 'zainteresowanie'; 'interesować', następnie 'sprawa'; 'przedsięwzięcie przynoszące korzyść', a od XIX w. 'przedsiębiorstwo', 'zakład przemysłowy', 'sklep' ”, s. 190.
} 
zainteresowania dostrzegamy tu raczej redukcję pragmatyczno-semantyczną do czysto utylitarnej. Jednak $\mathrm{z}$ drugiej strony to nic nowego. Od czasów starożytnych przeciwstawiano rozumne pragnienia, zgodne $\mathrm{z}$ istotą $\mathrm{i}$ celowością człowieka, jego dążeniu do przyjemności, bogactwa czy władzy. Zatem o ile język potoczny stopniowo nie tyle narzucał słowu inter-esse i całej jego rodzinie wyrazowej sens ekonomiczno-merkantylny, to filozofia podtrzymywała i ciagle upominała się o ten bardziej źródłowy sens słowa inter-esse jako zainteresowania. Tak postępował nie tylko Platon, Arystoteles, Augustyn czy Tomasz z Akwinu, ale w nowożytności Tomasz Hobbes u podstaw aktywności człowieka i struktur społecznych ulokował ludzką interesowność. Punktem wyjścia dla etyki utylitarystycznej uczynił ją J. Bentham, który zrazem uważał, że termin ten nie daje się zdefiniować. Pisał: „Interes społeczeństwa to jeden z najbardziej ogólnych terminów, jakie możemy spotkać we frazeologii nauki o moralności, nic więc dziwnego, że często zatraca się jego znaczenie" "Immanuel Kant nie chciał zaakceptować interesu jako fundamentu etyki, ale pragnął ludzkiej nierozumnej naturze (skłonnościom) narzucić rozumną formę, lokując jej źródło w autonomicznym czystym rozumie praktycznym. Któż nie szedł tą drogą? Etyka nie ma innego wyjścia, jak albo interesowność uczynić swoją przesłanką i stać się zbiorem reguł mediacji w konfliktach interesów, albo interesy uczynić przedmiotem wyrzeczenia torującego drogą bezinteresowności dostęp do racji doskonałości, obowiązku czy odpowiedzialności.

Zatem z jednej strony traktujemy ludzkie dążenia, czyli interesy jako fundament i okno na świat wartości, jak czynił to na przykład na gruncie neorealizmu i pragmatyzmu amerykańskiego R.B. Perry, w twierdzeniu, że wartość jest jakimkolwiek przedmiotem jakiegokolwiek zainteresowania (value is any object of any interest $)^{8}$, co od razu wywoływało krytykę w Europie (W.D. Ross) ${ }^{9}$.

Spór o naturę interesu lub zainteresowania trwa. Nie tak dawno tym drugim tropem prowadził swoje myślenie etyczne E. Lévinas, który pisał: „Esse jest interesse. Istota jest interesownością. [...] W sposób pozytywny interesowność potwierdza się jako conatus bytów. [...] Interesowność bycia rozgrywa się jako walka egoizmów, które walcząc ze sobą są dzięki temu razem" ${ }^{10}$. Filozof ten jednak idzie dalej ku racjom wzniesienia się ponad intere-

\footnotetext{
${ }^{7}$ Por. J. Bentham, Wprowadzenie do zasad moralności i prawodawstwa, thum. B. Nawroczyński, Warszawa 1958, s. 19.

${ }^{8}$ Por. R.B. Perry, General Theory of Value, New York 1926.

${ }^{9}$ W.D. Ross, The Right and the Good, Oxford 1930.

${ }^{10}$ E. Lévinas, Inaczej niż być lub ponad istota, thum. P. Mrówczyński, Warszawa 2000, s. 13.
} 
sowne bycie, ku bezinteresownej odpowiedzialności za Innego. Dlatego byciu w interesowności, redukcji każdego sensu naszego języka do interesowności, przeciwstawia on to, co inne od bycia, podmiotowość rozumianą poza byciem i nie-byciem, z jej rozwiniętą wrażliwością. Pisze: „Rozum, któremu przypisujemy cnotę powstrzymania przemocy - aby osiagnąc porządek pokoju - zakłada bezinteresowność, bierność lub cierpliwość. W tej bezinteresowności [...] zarysowuje się sprawiedliwość, która porównuje, zbiera i myśli, synchronia bycia i pokoju"11. Interesowi została tu przeciwstawiona bezinteresowność, ale bynajmniej nie wartości osadzone w kondycji ludzkiej interesownej egzystencji. Mimo zawirowań językowych usiłujemy odwiecznie, w tej lub innej formie, już to wykorzystać, już to ograniczyć naszą naturalną interesowność i nasze zainteresowania uszlachetnić bądź radykalnie przeciwstawić im racje należące do innego porządku logicznego (transcendentnego lub transcendentalnego).

Motyw w duchu perypatetyckim, polegający na uczynieniu punktem wyjścia aktów pożądania, pragnienia, zainteresowania, oceniania - jakkolwiek się te akty nazwie i zinterpretuje - z gruntu empirystyczny, funkcjonuje jednak we współczesnej aksjologii i etyce, bynajmniej nie pozostając czysto sprawozdawczym (socjologicznym czy psychologicznym punktem widzenia wartości). Franz Brentano już przed ponad stu laty osadził etykę na aktach emocjonalnego dążenia i unikania, nazywając je zdecydowanie miłością i nienawiścią względem przedmiotu (może zbyt radykalnie), ale pod kontrolą intuicyjnej oceny słuszności i niesłuszności tych aktów ${ }^{12}$. Nie pozostało to, jak wiadomo, bez wpływu na fenomenologiczną teorię wartości, bodajże najbardziej znaną dwudziestowieczną filozofię wartości.

W tradycji Brentana utrzymana jest filozofia wartości Tadeusza Czeżowskiego, czołowego reprezentanta szkoły lwowskiej, ucznia Kazimierza Twardowskiego. Jego koncepcja empirii aksjologicznej (etyki empirycznej) polega na przyjęciu za podstawę poznania aksjologicznego intuicyjnie danych treści zawartych $\mathrm{w}$ doświadczeniu wartości, wymagających jednak przyjęcia i doskonalenia postawy oceniającej. Indukcja treści doświadczenia pozwala sformułować sądy określające kryteria aksjologiczne (etyczne, estetyczne, hedoniczne), które jednak pozbawione są statusu poznania pewnego, zachowując jednak pro-

${ }^{11}$ Tamże, s. 33-34.

${ }^{12}$ Por. F. Brentano, O źródle poznania moralnego, tłum. C. Porębski, Warszawa 1989, s. 2021 - gdzie czytamy: „Spośród dwóch przeciwstawnych sposobów zachowania się - miłowania i nienawidzenia, znajdowania upodobania i odczuwania niechęci - w każdym przypadku jeden i tylko jeden jest słuszny, drugi - niesłuszny. [...] Rzecz nazywamy dobra, gdy słuszna jest skierowana ku niej miłość". 
babilistycznie określony status poznawczy. To jest etyka budowana „od dołu”, indukcyjnie ${ }^{13}$. Czeżowski jednak - wbrew interpretacjom kwalifikującym go do etyki indukcyjnej, ustalającej co w wiodących ocenach uważane jest za wartościowe, bynajmniej, broniąc naukowej attyki i filozofii wartości, nie chciał traktować etyki opartej o oceny wartości jako wiedzy o dominujących w społeczeństwie ocenach moralnych. Wysunął bowiem z czasem wyraźnie postulat etyki hipotetyczno-dedukcyjnej, budowanej „od góry”, która metodą opisu analitycznego tworzy aksjomat wartości moralnej na podstawie ograniczonego zakresu doświadczenia, a następnie poddaje go interpretacji, czyli sprawdzeniu w polu semantycznym utworzonym przez intuicje moralne $\mathrm{i}$ ich indukcje. Tak pojęta etyka przybiera postać formalnie prawdziwej teorii deontycznej, tworząc ramy dla niepewnego i ciagle pomnażanego doświadczania wartości. W stopniu, $\mathrm{w}$ jakim teoria deontyczna znajduje potwierdzenie $\mathrm{w}$ wartościach praktyki moralnej, zachowuje swoją ważność. Jeśli jednak zawodzi, funkcjonuje poza praktyka, obok zupełnie innych doświadczeń tego, co dobre, co złe, traci ważność materialna, czyli przestaje obowiązywać ${ }^{14}$.

Lekcja aksjologii i etyki empirycznej Czeżowskiego pokazuje, w jaki sposób empiryczny punkt wyjścia w aksjologii systematycznej, zmierzającej do ujęcia uniwersalnego systemu wartości, a w szczególności etyki w swoich roszczeniach uniwersalnej, może przybrać postać takiego systemu. Nie daje to jednak, jak widać, efektu w postaci empirycznie i zarazem ogólnie ważnej teorii wartości lub moralności. Pewną próbę dojścia do takiej teorii przedłożył na gruncie etyki, w nawiązaniu do koncepcji Czyżowskiego, Tadeusz Styczeń $^{15}$. Problemami tymi zajmowałem się wcześniej, wskazując na trudności metodologicznie wiązania empirii aksjologicznej z uniwersalnie ważnym system wartości lub moralności ${ }^{16}$. Historia dowodzi, że jeśli etyka czy aksjologia zrywa $\mathrm{z}$ empirią w punkcie wyjścia, musi ją ostatecznie, o ile miałaby spełniać swe funkcje praktyczne, znaleźć i określić dojście do doświadczenia wartościującego w punkcie dojścia. Było to zapewne także udziałem transcendentalnej etyki Kanta, do którego czas pokrótce się odnieść w związku $\mathrm{z}$ naszą analizą pojęcia i doświadczenia interesu.

${ }^{13}$ T. Czeżowski, Etyka jako nauka empiryczna, „Kwartalnik Filozoficzny”, t. XVII, 1949, s. 161-171; także: „Philosophy and Phenomenological Research”, vol. XIV, 1953, nr 2; powtórzone w: Odczyty filozoficzne, Torun 1959. Cytowane wyd. II popr. i uzupeł., Toruń 1969, s. 40-45.

${ }^{14}$ Por. T. Czeżowski, Aksjologiczne i deontyczne normy moralne, „Etyka” nr 7, Warszawa 1970, s. 137-138.

${ }^{15}$ Por. T. Styczeń, Problem możliwości etyki jako empirycznie uprawomocnionej i ogólnie ważnej teorii moralności. Studium metaetyczne, Lublin 1972.

${ }^{16}$ Najobszerniej uczyniłem to w rozprawie: R. Wiśniewski, Możliwość probabilizmu etycznego. Studium metaetyczne empiryzmu w etyce polskiej, Torun 1992. 
Współcześnie interesy uważane są dość powszechnie za fundament partykularyzmu, ograniczający czy wręcz uniemożliwiający przyjęcie i praktykowanie uniwersalnego systemu wartości oraz w ślad za tym - uniwersalnej moralności. Od normy moralnej wymaga się przecież, aby mimo swej źródłowej subiektywności była zrazem uniwersalna, aby można było ją uznać jak to ujmował Kant - za ,powszechne prawo”, czyli traktować tak jak „,ogólne prawo przyrody", to znaczy konieczne prawo przyrody dla wszystkich istot rozumnych ${ }^{17}$. Spójrzmy jednak na słynny imperatyw kategoryczny Kanta w perspektywie, która być może wcale nie była mu obca, którą dopuszczał, mając przecież wyczucie realizmu życiowego.

Chodzi o to, że formuła imperatywu kategorycznego wcale nie wydaje się unieważniać naszych interesów (zainteresowań), ale żąda raczej, aby wznosić się ponad nie w imię rozumu kierującego postępowaniem, a ten nakazuje: postępuj tylko wedtug takiej maksymy, dzięki której możesz zarazem chcieć, żeby stała się powszechnym prawem $^{18}$. Nie ma tu miejsca i nie chcę wchodzić w subtelne analizy wypowiedzi Kanta, ale nie sposób odczytywać tego imperatywu jako formułowanego w pełnej świadomości konieczności wznoszenia się ponad osobiste, partykularne interesy czy zainteresowania. Nie o to więc raczej chodzi, aby człowiek zawsze poddawał restrykcji swoje interesy (korzyści), ale żeby w sytuacji konfliktu potrafił wznieść się ponad interesy. $\mathrm{Na}$ gruncie dyskursu moralnego może więc to znaczyć, że nasze interesy nie muszą być z definicji sprzeczne z moralnością. Kant nieustannie posługuje się słowem ,zarazem", a to znaczy, że nie tylko przeciwstawia sobie interesy i moralność, skoro daje pod rozwagę kwestię, czy moglibyśmy zrazem chcieć czegoś jako reguły moralności powszechnej. Wydaje się więc, że termin bezinteresowność jest swego rodzaju nadużyciem semantycznym na gruncie etyki, która chciałaby zachować status realistycznej, ujmującej rzeczywistość w prawdzie ludzkiego bytu. Nie o to chodzi, aby człowiek wyrzekł się interesu, ale by nadał mu właściwe znaczenie w swoim życiu. Interes nie powinien być redukowany do ekonomicznej interesowności, ale traktowany jako rozumne pragnienie, otwarcie na wartości. Nie traktuję tego jako arbitralnego postulatu, lecz jako wynik analizy niepowodzeń praktycznych etyki, która w zapędzie do formowania ludzkiego zachowania na idealną modłę zapominała o człowieku, który żyje na Ziemi. Nie jest przypadkiem, że liczni współcześni filozofowie moralności (B. Williams, R. Hare, a także etycy cnoty)

${ }^{17}$ Por. I. Kant, Uzasadnienie metafizyki moralności, thum. M. Wartenberg, przekł. przejrzał R. Ingarden, wyd. II, Warszawa 1971, s. 50, 51, 58.

${ }^{18}$ Tamże, s. 50. 
starają się znaleźć modus vivendi między etyką utylitarystyczną a deontologią uformowana przez I. Kanta.

Niedopasowanie etyki do życia ma źródło w dychotomicznym przeciwstawianiu ludzkich pragnień czy interesów, rozumianych tu jako wartościowania obiektywnym i absolutnym wartościom oraz powinnościom. To zbyt ostre napięcie, zbyt trudne dla człowieka, aby mógł się stopniowo wznosić ku wyższym wartościom, sprzyja instrumentalnemu traktowaniu języka moralności przez polityków, media i demagogów różnej proweniencji, terroryzujących moralnie normalnych ludzi. Tymczasem bliższa jest nam postawa „robola” niż „archanioła” (R. Hare). Etyka powinna być bliższa - by użyć metafory nawiązującej do S. Lema - praktyki normalnego krawca niż szalonego krawca. O ile pierwszy szyje ubiór na miarę człowieka, to drugi ma gotowy garnitur i kroi klienta.

To głębokie wyczucie i racjonalizacja uniwersalnej natury wszelkiego prawa moralnego, a zrazem potrzeby wzniesienia ponad własny interes towarzyszy odwiecznie refleksji moralnej i próbom jej teoretycznego ujęcia w postaci teorii etycznej. Idzie to jednak niekiedy tak dalece, że budzi opór i wezwanie do troski o siebie, o potrzebę ekspozycji racji wynikających z partykularnego punktu widzenia. W dziejach filozofii moralnej i na jej antropologicznych obrzeżach problemowych widać nieustanne balansowanie między potrzebą obiektywizmu i uniwersalizmu a respektem dla konkretu, w którym ujawnia się subiektywna perspektywa rzeczywistości, jej niepowtarzalna sytuacyjność, nieredukowalność do tego, co uniwersalne. Nietrudno zaobserwować chwiejność między partykularyzmem a uniwersalizmem, między osadzeniem dyskursu etycznego w fakcie jednostkowych czy grupowych interesów a wymogami ich oceny moralnej $\mathrm{w}$ perspektywie uniwersalizmu aksjologicznego i etycznego.

\section{UŻYTECZNOŚĆ I GODNOŚĆ}

Pozostając w klimacie inspiracji Kantowskich zwróćmy uwagę na kolejny problem aksjologiczny i etyczny, ukazujący trudność pogodzenia racjonalnego namysłu nad rzeczywistością z językiem publicznego dyskursu etycznego. W imperatywie praktycznym Kant wypowiada następującą formułę: „Postępuj tak, byś człowieczeństwa tak w twej osobie, jak też w osobie każdego innego, używał zawsze zarazem jako celu, nigdy tylko jako środka"19. Po-

${ }^{19}$ Tamże, s. 62. 
wszechny odbiór tego prawidła moralnego sprowadza się, nawet w poważnych podręcznikach, do formuły żądającej traktowania człowieka jako celu, a nie jako środka. W imperatywie tym znajdujemy na ogół nakaz szacunku dla ludzkiej podmiotowości. Kontynuując jednak nasz zamiar łagodzenia i przezwyciężania dychotomii interesów i wartości, użyteczności i godności, trzeba wskazać w cytowanych do znudzenia i niezbyt dobrze rozumianym imperatywie przesłanie, które pozwala nam wiązać do pewnego stopnia korzyści wynikające z ludzkich więzi z szacunkiem dla tego, co do tych więzi jest nieredukowalne - do godności ludzkiej. Zdumiewające jest, że w dyskursie potocznym wolimy przeciwstawiać użytek godności. Tymczasem Kant wyraźnie, przy całym znowu swoim realizmie, zgadza się na używanie walorów człowieczeństwa własnego i cudzego, ale wpisując tam słowa „zarazem” i ,nie tylko" oczekuje, że nie doprowadzi to redukcji człowieczeństwa do czystego użytku. To bowiem naruszałoby ludzką godność, samo-celowość, przynależność do „państwa celów”. Kant pisze dalej: „W państwie celów wszystko ma albo jakąś cenę, albo godność. To, co ma cenę, można zastąpić także przez coś innego, jako jego równoważnik, co zaś wszelką cenę przewyższa, a więc nie dopuszcza żadnego równoważnika, posiada godność" ${ }^{20}$. Rozróżnienia są jasne i wprowadzają one europejską etykę na trop rozpoznawania ludzkiej godności, jako wartości nieredukowalnej do użytku, nie usprawiedliwiającej zrównoważenia jej jakąkolwiek ceną. Godność nie ma ceny rynkowej, nie może być przedmiotem umowy pracy (mobbing) czy jakiejkolwiek innej. Osoba ludzka w swoim człowieczeństwie buduje godność poprzez rozpoznawanie i realizowanie wartości przekraczających poziom jej naturalnych interesów i użytków. Kant zaszczepił nam myśl, że człowiek, jakkolwiek uczestniczy w grach interesów i użytku, nie może być zredukowany do wartości użytkowej, że stanowi węzeł aksjologiczny nie podlegający regułom wymiany.

Mankamentem dyskursów publicznych na temat godności jest to, że przeciwstawia się w nich godność użytkowi, jakby sam użytek destruował godność, podczas gdy powinno się potępiać redukcję człowieczeństwa do użytku, niezdolność dostrzegania w człowieku jego autotelicznej wartości, osobowości. Zdolności użytkowe człowieka, zdolność do zawiązywania stosunków oparty na pożytku, to fundament cywilizacji. Zauważył to już Arystoteles, umieszczając przyjaźń dla pożytku u podstaw wykładu o przyjaźni, jakkolwiek wyżej ceni on przyjaźń dla przyjemności, a przede wszystkim dla zalet przyjaciela. Przyjaźń etyczna nie wyklucza jednak przysług ${ }^{21}$. Użytek (ko-

\footnotetext{
${ }^{20}$ Tamże, s. 70.

${ }^{21}$ Arystoteles, Etyka nikomachejska, Księga VIII. Arystoteles ma wprawdzie zrozumienie dla
} 
rzyść) nie ma znamion moralnych, więzi dyktowane użytkiem nie są same w sobie moralne, jeśli kryterium moralności miałyby być cnotą, godność czy posłuszeństwo prawom moralnym, które cnocie i godności sprzyjają. Wartości użytkowe są jednakowoż dobrami moralnie relewantnymi, tworzącymi fundament współżycia i współdziałania. Cywilizacja jest gęstniejącą siecią relacji użytkowych, ale tym, co ją czyni ludzka, jest zdolność powstrzymania się od redukcji i samo-redukcji wszystkich relacji do użytku. Znowuż więc zadanie nie polega na wyrzeczeniu się relacji użytkowych, ale na moralnej kulturze ich traktowania ${ }^{22}$.

\section{FILOZOFIA WARTOŚCI A DEBATY PUBLICZNE}

Miejsce filozofów w debacie publicznej o wartościach przejęli socjolodzy i psycholodzy społeczni, dla których wartości to ,idee, zjawiska, materialne i niematerialne przedmioty, stany, rzeczy, osoby, grupy itp., które są przez jednostki, warstwę, grupę, klasę społeczną itp. dodatnio bądź ujemnie oceniane czy aprobowane lub odrzucane. Stanowią jeden z głównych wyznaczników i celów ludzkiego działania"23. Traktują je oni jako fakty społeczno-kulturowe, psychiczne, emocjonalne, ale przy okazji, nie zawsze świadomie, przekraczają granice deskrypcji i teorii, dokonując autorytatywnych ocen i rekonstrukcji. To oni kształcą speców od marketingu, wizerunku, public relations, uczestnicząc mniej lub bardziej pośrednio w grach rynkowych, politycznych, medialnych. Język interesu stał się bardziej wymierny w tym świecie niż język wartości. Świat w tej perspektywie porządkują interesy, a nie zredukowane do emocji wartości. Język wartości został w rezultacie dalece zinstrumentalizowany jako narzędzie sterowania emocjami (wartościami bardziej przyziemnymi), stał się narzędziem perswazji medialnej, politycznej, rynkowej. Powstał zamęt aksjologiczny, któremu brakuje bardziej stabilnego punktu odniesienia. Filozofowie wydają się bezradni, ludzie sztuki, literatury również.

To, że o wartościach mówi się jako uczuciach, postawach, poziomach aprobaty, że w komentarzach medialnych ze strony socjologów czy politologów traktuje się politykę, jak sztukę zarządzania uczuciami w przestrzeni publicznej, jest oczywistym pokłosiem emotywizmu w naukach społecznych.

przyjaźni z powodu pożytku i przyjemności, ale nie jest dość konsekwentny, skoro w we fragmencie 1157 b nazywa ich ludźmi złymi.

${ }^{22}$ Por. W. Tatarkiewicz, Cywilizacja i kultura, w: tegoż, Parerga, Warszawa 1978 - gdzie autor obiektywistycznie rozumie cywilizację jako strukturę instytucjonalną, a kulturę jako zdolność subiektywnej partycypacji i twórczości.

${ }^{23}$ K. Olechnicki, P. Załęcki, Stownik socjologiczny, Toruń 2000, s. 239. 
Dostrajają się do tego także filozofowie, twierdząc że język wartości jest perswazyjny, bezużyteczny poznawczo, wskazując na kłopoty z ontologicznym ujęciem wartości. Co można więc ze strony filozofii temu przeciwstawić?

W sytuacjach kryzysu proponuje się powrót do źródeł. To droga, do której nawołuje A. MacIntyre w Dziedzictwie cnoty. Oznacza to powrót do Arystotelesa dla tych, którzy dawno o nim zapomnieli, ale nie dla wszystkich. Stagiryta radził „zaczynać od tego, co jest nam znane" 24 . Interesy i zainteresowania wydają się wprawdzie subiektywne i lepiej nam znane, ale mogą być intersubiektywizowane, podlegać dialogowi, bynajmniej nie czysto użytkowemu, co nadaje im przynajmniej w wymiarze społeczno-kulturowym cech quasi-obiektywnych. Wydają się wartości wtedy obiektywne, niezależne, nieustanawiane przez nas, tworzące wspólną przestrzeń aksjologiczną (strefę zgody, integracji, porządku, interesu ogólnego, odpowiedzialności, wiary). O wartościach można i trzeba dyskutować, aby zrozumieć przede wszystkim ich związki i to, że z trudem dają się systematyzować.

Dyskurs wartościujący prowadzi do wiedzy, że wśród dóbr, do których aspirujemy, ogromna większość ma status wartości względnych ${ }^{25}$, co znaczy, że nie posiadają wartości autotelicznej, że zawdzięczają je wartościom bezwzględnym, zwanym też absolutnymi, niezwiązanymi. Względne wartości są abstrakcjami relacji wewnątrz systemu rozmaitych zależności, sieci, zbudowanej z rozmaitych podsystemów, dynamicznie rozwijających się. Taki obraz świata wartości sugerowany przez niektórych pragmatystów (Dewey) jawi się jako coś nie do ogarnięcia w całości. Żyjemy na co dzień w świecie dóbr względnych (konkretnych indywidualnych rzeczy, stanów rzeczy, postaw), gubimy się, ale jednakowoż zauważamy, że są tu jakieś trwalsze węzły, niezmienniki, wartości bezwzględne, które wybieramy dla nich samych. Często nazywa się je po prostu wartościami, podczas gdy tamte względne nazywa się zwykle dobrami. $Z$ powyższego wynika, że jest jakieś przejście od języka interesu i zainteresowania do języka wartości.

Droga porządkującego poznania wartości ma jeszcze inną swoistość. Pytamy bowiem o wartość najwyższą, bowiem wartości bezwzględne również są uwikłane w relacje (zależności) i bynajmniej - moim zdaniem, choć nie czuję się tu odosobniony - nie zasługują na miano absolutnych. Prawda bywa pożyteczna, wolności się używa, ze sprawiedliwości też ma się różne pożytki. Przez wartości absolutne rozumie się wartości niezwiązane, wolne od jakichkolwiek powiązań. Wartości bezwzględne są wpisywane w system, abso-

\footnotetext{
${ }^{24}$ Arystoteles, Etyka nikomachejska, s. 81.

${ }^{25}$ Por. W. Tatarkiewicz, Problemy aksjologii, s. 811.
} 
lutne wydają się nadsystemowe, jako punkty lub tylko jeden punkt odniesienia. Ich się nie używa, nie oczekuje się korzyści z tytułu jakieś relacji do nich. Wartość absolutna zdaje się więc aksjologicznie uprawomocniać cały świat wartości, bez potrzeby wsparcia się na nim, czyli legitymizowania się swoimi konsekwencjami. Ktoś powie, że to mistyka wartości, jaką uprawiał niedawno Henryk Elzenberg. Jakaż może być treść tej wartości? Mówi o niej religia, ale także refleksja nad ludzką godnością. Obie drogi odczuwania tego, co w świecie wartości jest absolutne, nie są, jak sądzę, sprzeczne ze sobą, nie wykluczają się. Ważne jest, żeby te drogi nie odcinały się od tego, czym żyje człowiek.

Powróćmy zatem jeszcze w stronę życia publicznego. Sprzeczny z naturą wartości absolutnych jest odwieczny i krytykowany sposób traktowania wartości godnościowych i religijnych. Chodzi o ich instrumentalizację względem ludzkich interesów. Ludzie usiłują od wieków włączyć w różnych religiach swoich bogów w służbę swoich interesów, podczas gdy jedyną relacją respektującą status Boga względem człowieka w danej religii wydaje się być rewerencja i odpowiedzialność (posłuszeństwo). Podobnie też w życiu społecznym ludzie swoją godnością rozporządzają jak wartością wymienną. Dyskurs publiczny jawi się więc nierzadko bluźnierczym i obłudnym, zawłaszczającym wartości religijne czy godnościowe dla gier czy praktyk czysto utylitarnych, marketingowych.

Umiejętność poprawnego i konsekwentnego hierarchizowania wartości jest rzadką umiejętnością. Osoby publiczne przypisując sobie mądrość i autorytet na podstawie demokratycznych sposobów wyłaniania elit, mówią często o wartościach jakby racja była także $\mathrm{w}$ tych sprawach po stronie większości, nie potrafią odróżnić demokratycznej woli od racji aksjologicznych. Tak się dzieje w prawodawstwie i musi budzić zrozumienie krytyka opierania ustawodawstwa na zmiennych dominantach wartościowań (E.W. Böckenförde).

U podstaw mojego artykułu leży troska o stan etyki i jej odbioru publicznego, a także w szczególności nagminne zakłócanie języka komunikacji publicznej deklaracjami etosu bezinteresowności. Zapewniają o tym bez mała prawie wszyscy uczestnicy życia publicznego i mają w tym pewne wsparcie w literaturze filozoficznej tudzież w sposobie jej odczytywania, tym najłatwiejszym, szukającym różnicy, a rezygnującym z uchwycenia związku między tym, co różne. Bezinteresowność tymczasem zdaje się przeczyć naturze człowieka i jego stosunku do zapośredniczonych lub ujawniających się w ludzkich interesach wartości.

Należy oczekiwać dokładniejszych filologicznych badań porównawczych, wyjaśniających, jak to się stało, że termin „bezinteresowność” jest sprzeczny 
ze zdrowym rozsądkiem. Na gruncie języka polskiego, ale także innych języków, łatwo zauważyć, że słowo wynika z potrzeby nazwania aksjologicznej opozycji względem interesowności. Człowiek bezinteresowny, czytamy w słownikach, to działajacy nie dla własnego interesu, nie szukajacy osobistych zysków, gratisowy ${ }^{26}$. Zatem każdy kierujący się wspólnym interesem działa bezinteresownie. Można ostatecznie tę pragmatykę językową zaakceptować, ale warto też zauważyć, że jest ona dość istotnym elementem gry językowej, w której bliskoznaczność terminów sprzyja nadużyciom semantycznym. Lepiej byłoby określać jawnie swoje interesy względem wspólnych, publicznych interesów niż udawać obłudnie czy wstydliwie bezinteresownego. Wymagają tego normy transparentności publicznej. Deklaracja bezinteresowności jest wewnętrznie pod względem antropologicznym i aksjologicznym sprzeczna, dlatego, że to nie wyrzeczenie, oczyszczenie się z interesów własnych jest podstawą służby dobru wspólnemu, ale swoista asceza pozytywna, porządkująca nasze osobiste interesy $\mathrm{w}$ harmonii $\mathrm{z}$ interesami, czyli wartościami wspólnoty. Kiedy wykładam etykę urzędniczą, etykę życia publicznego i etykę biznesu, nie widzę żadnych podstaw do włączania w system zasad bezinteresowności. To kończy porozumienie ze studentami. Podobnie przed laty Czeżowski, krytykując polityczną partyjność nauki, bronił jej zaangażowania po stronie prawdy i innych wartości poznania naukowego. Z podobnych względów stopniowo pozbyliśmy się złudzeń potrzeby i możliwości propagowanego przez M. Webera projektu nauki wolnej od sądów wartościujących.

Język, w którym wartości przeciwstawia się interesom, a godność użyteczności, i dość ogólnikowo te kwestie się traktuje, sprzyja atmosferze podejrzliwości, nieufności, tropienia interesu w każdym wymiarze działania. Przykładem niech będzie Kodeks etyczny stużby publicznej, w którym zaleca się urzędnikom unikanie podejrzeń o związek interesu własnego z interesem publicznym, pomijając przypadki takie jak ten, że interes publiczny wyrastać może i realizować na bazie gry interesów prywatnych z publicznymi, że raczej należy unikać konfliktu interesów, w których jedna ze stron jest pokrzywdzona - na co zwracają uwagę inne kodeksy etyczne. Krótko mówiąc, zamiast szermować wartością bezinteresowności definiujmy i określajmy jasno nasze interesy. Traktujmy wartości jako wyższe, zuniwersalizowane interesy.

Powyższe rozważania miały na celu przeciwstawienie się dwu tytułowym dychotomiom semantycznym. Interesy i wartości mimo swej różnicy, często

${ }^{26}$ Maty stownik języka polskiego, s. 39. 
uchwytnej w kontekście, w świetle tego artykułu tworzą swoiste kontinuum i związek. Interes wskazuje na wartości subiektywne i najczęściej względne, wartości względne (utylitarne) nie miałyby statusu wartości, gdyby nie były w relacji aksjologicznej instrumentalności czy wtórności w stosunku do wartości dóbr bezwzględnych. Użyteczność stanowi aksjologiczną, instrumentalną strukturę cywilizacji, ale nie powstałaby i nie rozwijałaby się, gdyby nie wyrastająca $z$ ducha kultury zdolność do głębokiego i twórczego przeżywania i realizowania wartości, w szczególności wartości bezwzględnych i absolutnych. Te ostatnie zawierają się w ludzkiej godności i definiowane są w religiach.

Dyskurs publiczny jako gra językowa, rządząca się regułami skuteczności komunikacyjnej i praktycznej, deformuje aksjologiczne intuicje wartości i próby ich uporządkowania, systematyzacji. Hipotetycznym powodem tego jest wspomniana dychotomia znajdująca odbicie w sposobach budowania systemów aksjologicznych i teorii etycznych, w których porządek interesów i użyteczności występuje w ostrym przeciwstawieniu porządkowi wartości i godności. Sądzę, że potrzebna jest teoria, która tę sytuację przezwycięża.

\section{SUMMARY}

The analyses included in this article are meant to oppose two semantic dichotomies included in the title. Interests and values in the light of the article stay in a certain continuum and strict connection. Utility is axiological and instrumental structure of civilization but it develops owing to the capacity to live and realize values, especially absolute ones. They are included in the idea of human dignity and defined in religions. Public discourse as a language-game often deforms axiological intuitions of values and attempts to arrange and systematize them. Hypothetically it results from the mentioned dichotomy generating juxtaposition of the order of interests and utility with the order of values and dignity. The theory which overcomes this situation is needed.

\section{Key words:}

axiology, interests, value, utility, dignity, Kant 